\title{
Undergraduate Medical Curriculum: Relevance and Appropriateness to Community's Health Needs
}

\author{
Narjis Rizvi*1, Anam Feroz ${ }^{1}$ and Sana Tanzil ${ }^{3}$ \\ ${ }^{1}$ Department of Community Health Sciences, Aga Khan University, Pakistan \\ ${ }^{2}$ Appna Institute of Public Health, Jinnah Sindh Medical University, Pakistan
}

Received: May 28, 2018; Published: June 14, 2018

*Corresponding author: Dr.Narjis Rizvi, Department of Community Health Sciences, Aga Khan University, Karachi, Pakistan

\begin{abstract}
Despite doubling of the lifespan because of scientific medical education; inequities in healthcare provision exist.Inadequate priority to community's health needs in undergraduate medical curricula could be one of the contributors. Aga Khan University, Pakistan pioneered community-based undergraduate curriculum for addressing community's health needs. This paper assesses relevance and appropriateness of this undergraduate medical curriculum to community's health needs.This study has used a framework, consisting of three major parameters including public health concepts, major public health problems and attributes, to assess the relevance and appropriateness of Aga Khan University's undergraduate curriculum to community's health needs.This assessment revealed that for relevance and appropriateness to community's health needs, the curriculum hasto be community-based.The community-based experiential learning helps students to identify context-specific health needs and develop culture-sensitive practices. This approach is difficult to operationalize in developing countries where national health systems focus curative care at tertiary hospitals primarily and community-based primary healthcare facilities are mostly nonfunctioning. Another challenge is training and retention of community-based teaching faculty. We recommend community-based medical education so that; competencies are matched with population needs, primary care and community health are given priority and leadership and team work skills are imparted among health professionals.
\end{abstract}

Keywords: Spice; Prism; Core; Multilateral Donor Projects; Pedagogy; Empathetic; Population; Epidemiology; Biostatistics; Health Systems, Primary Health Care; Reproductive Health

Abbreviations: COCB: Community-Oriented and Community Based; AKUMC: Aga Khan University Medical College; CHS: Community Health Sciences; PMDC: Pakistan Medical and Dental College; HEC: Higher Education Commission; AKMCH: Aga Khan Medical College Hospital; CHWs: Community Health Workers; LHWs: Lady Health Workers; PLHF: Primary Level Healthcare Facilities; DHMIS: District Health Management Information System

\section{Background}

Based on the recommendation of educational reforms, modern science was integrated into medical curricula [1]. This integration contributed to the doubling of life span during the 20th century [2]. Conventional undergraduate medical schools use curative care model where healthcare is patient-centred and learning mainly takes place at hospitals. In this model the curriculum designing is; teacher-centred, knowledge-focused, discipline-led, hospitalbased, standardized and opportunistic [3]. Recognition of health inequities due to socio-economic determinants across countries/ communities, however, led to the ground-breaking Alma-Ata Primary Health Care conference.Subsequent to this conference, a global demand for centrality of community in healthcare designing was generated.This was further endorsed by Edinburg declaration later [4].
For translating these international commitments into action, World Federation of Medical Education, many governments and regional medical education bodies called-for worldwide changes in health professional education.This call was to ensure that medical graduates' are adequately and appropriately trained to improve the health of the population.The ideology that sensitization to community's health needs and interdisciplinary approach are mandatory for the improvement of population's health was a paradigm shift in the template for planning and designing medical education curricula [5]. The 'SPICE' model laid the foundation of the community-oriented content of medical education and recommended the curriculum to be student-centred, problembased and integrated [6]. Later, the 'PRISMS' model introduced community-based pedagogy in medical education recommending 
the curriculum to be practice-based, inter-disciplinary, multisite and symbiotic with the health services and communities in which the health professionals serve [7].

The Community-Oriented and Community-Based (COCB) medical education was pioneered in Pakistan in 1983 by the Aga Khan University Medical College (AKUMC) with the aim to translate AKUMC's vision into action; 'develop physicians who can serve the health needs of the poor, vulnerable and underserved populations of the country'.The department of Community Health Sciences (CHS) was established to design and launch COCB. The CHS designed COCB undergraduate public health curriculum based on Spitzer's Report [8] to bring science closer to humanism.This newly designed COCB undergraduate public health curriculum introduced many innovations in the content and pedagogy and has been in place for the last three decades.Very little robust evidence, if any, is available about the effectiveness of educational reforms launched by many institutions in the region [9]. Realizing this, a need was felt to review and document the design and implementation of AKUMC's undergraduate public health curricular model, and wisdom acquired so far. This paper is based on this review and has: assessed the relevance and appropriateness of the undergraduate public health curriculum to community's health needs; and documented success stories, challenges and lessons learnt.

\section{Methods}

The methods included document review and in-depth interviews.Since the objective was to assess relevance and appropriateness of the AKUMC's undergraduate public health curriculum to community's health needs, therefore, the knowledge on the community's public health needs was necessary. Identification of the community's public health needs was a daunting challenge.It had to be comprehensive and holistic ideally, yet focused and context-specific practically as everything cannot be covered in a curriculum of five years. Acknowledging that standard under-graduate medical education templates best determine the parameters of the health needs of the communities [10], the same templates were adapted to determine the parameters of the public health needs of Pakistani population.The parameters so selected included: nationally recognized public health concepts; evidencebased major public health issues; and attributes required for fulfilling societal needs.

These three selected parameters were used to assess the three essential dimensions of the undergraduate public health curriculum including knowledge, competencies and attributes [11]. In this way a framework of analysis was developed that consisted of three parameters and dimensions respectively, refer to Table 1. This framework was used to determine if AKUMC undergraduate public health curriculum's; conceptual basis and content is relevant to community's public health needs, and pedagogy appropriate to deliver knowledge, competencies and attributes to medical graduates.The documents reviewed included; AKUMC's vision, mission, attributes that AKUMC expects from its graduates, curricular goal, objective and schedule; national surveys and reports, national and international literature describing current morbidity and mortality burden and standards for content and pedagogical appropriateness; guidelines of the national statutory body namely Pakistan Medical and Dental College (PMDC) and Higher Education Commission (HEC).

Table 1: Framework of Analysis.

\begin{tabular}{|c|c|c|c|}
\hline Dimensions & \multicolumn{3}{|c|}{ Parameters } \\
\hline & $\begin{array}{c}\text { Community } \\
\text { Medicine } \\
\text { Concepts } \\
\text { and Skills } \\
\text { considered } \\
\end{array}$ & $\begin{array}{c}\text { Population } \\
\text { Health Needs } \\
\text {-Major } \\
\text { Public Health } \\
\text { problems } \\
\text { Standards }\end{array}$ & $\begin{array}{c}\text { Traits and } \\
\text { Attributes } \\
\text { required to be } \\
\text { inculcated in a } \\
\text { Physician-AKU's } \\
\text { curricular } \\
\text { Terminal } \\
\text { Onobjectives }\end{array}$ \\
\hline Skills & & & \\
\hline Attributes & & & \\
\hline
\end{tabular}

In-Depth Interviews $(\mathrm{n}=15)$ were conducted to understand and document implementation of AKUMC's undergraduate public health curriculum in terms of: success stories, challenges and lessons learnt. The participants were; AKUMC alumni as well those currently studying, medical faculty from AKU and other public and private medical colleges, public health specialists working in national and international Non-Governmental Organizations and government officials from health sector. Participants were selected purposefully as the objective was to involve those who are more knowledgeable about the issue under research and conversant with the circumstances prevailing. Semi-structured discussion guidelines were used to conduct interviews.

\section{Results}

The results are presented in three main sections; development of framework to assess relevance and appropriateness of the curriculum to community's health needs; assessment of the relevance and appropriateness of AKUMC's curriculum to community's health needs; and the process in terms of success stories, challenges and lessons learnt.

\section{Development of Framework to Assess Relevance and Appropriateness of the Undergraduate Public Health Curriculum to Community's Health Needs}

A list of core elements was determined for each of the three parameters selected for the identification of the public health needs i.e. core public health concepts and skills, major public health issues and essential attributes. These core elements are presented below under the three essential dimensions of the undergraduate curriculum (knowledge, competencies and attributes):

\section{Knowledge and Competencies}

Review of international commitments guided that public health curriculum can be termed relevant and appropriate if it is grounded into two principles; firstly, that health is a human right, and secondly that health is strongly linked to social determinants [12-16]. The "Core" public health concepts and skills were derived 
from: international statistics and literature that determine evidence-based public health issues on the basis of morbidity and mortality burden [17-20]; public health issues prioritized by national professional bodies [21] and government undergraduate medical curricula [21]. Refer Table 2 for lists of core public health concepts and skills and major public health issues.

Table 2: List of Core Public Health Concepts and Skills, Major Public Health Issues and Essential Attributes.

\begin{tabular}{|c|c|c|}
\hline $\begin{array}{l}\text { Core Public Health } \\
\text { Concepts and Skills }\end{array}$ & $\begin{array}{c}\text { Major public Health } \\
\text { Issues }\end{array}$ & Essential Attributes \\
\hline Health and Disease & $\begin{array}{l}\text { Childhood Diseases } \\
\text { like Diarrhea, Acute } \\
\text { Respiratory Infections, } \\
\text { Measles and other } \\
\text { infectious diseases }\end{array}$ & $\begin{array}{l}\text { Knowledgeable and } \\
\text { skillful }\end{array}$ \\
\hline $\begin{array}{l}\text { Epidemiology and } \\
\text { Research Methods }\end{array}$ & $\begin{array}{l}\text { Pregnancy related } \\
\text { issues like Post- } \\
\text { Partum Hemorrhage, } \\
\text { Eclampsia, Puerperal } \\
\text { Sepsis, Abortion and } \\
\text { Obstructed Labour }\end{array}$ & $\begin{array}{c}\text { Keen Learner- Self- } \\
\text { directed life-long } \\
\text { learner }\end{array}$ \\
\hline Biostatistics & $\begin{array}{l}\text { Malnutrition among } \\
\text { children and women }\end{array}$ & Leader \\
\hline $\begin{array}{l}\text { Health Systems } \\
\text { Planning and } \\
\text { Management }\end{array}$ & $\begin{array}{c}\text { Infectious } \\
\text { diseases including } \\
\text { Tuberculosis, Malaria }\end{array}$ & Critical thinker \\
\hline $\begin{array}{c}\text { Demography and } \\
\text { Population Dynamics }\end{array}$ & $\begin{array}{c}\text { Non-Communicable } \\
\text { diseases like } \\
\text { Hypertension, } \\
\text { cancers, Diabetes }\end{array}$ & Problem solver \\
\hline $\begin{array}{l}\text { Social and Behavioral } \\
\text { Sciences }\end{array}$ & Injuries and Accidents & $\begin{array}{c}\text { Team player -work in } \\
\text { health teams }\end{array}$ \\
\hline $\begin{array}{l}\text { Community } \\
\text { Development and } \\
\text { Partnership }\end{array}$ & Occupational Health & $\begin{array}{c}\text { Initiating and } \\
\text { participating in } \\
\text { change }\end{array}$ \\
\hline $\begin{array}{c}\text { Ethics, } \\
\text { Professionalism and } \\
\text { Communication }\end{array}$ & $\begin{array}{c}\text { Mental Health } \\
\text { including Depression } \\
\text { and Domestic } \\
\text { Violence }\end{array}$ & $\begin{array}{l}\text { Researcher- Evidence- } \\
\text { Based decision maker }\end{array}$ \\
\hline $\begin{array}{l}\text { Environmental Health } \\
\text { Sciences }\end{array}$ & & $\begin{array}{l}\text { Empathetic, tolerant, } \\
\text { responsible }\end{array}$ \\
\hline Occupational Health & & $\begin{array}{c}\text { Providing } \\
\text { Compassionate Ethical } \\
\text { and cultural best } \\
\text { possible care }\end{array}$ \\
\hline $\begin{array}{l}\text { Reproductive and } \\
\text { Child Health }\end{array}$ & & $\begin{array}{c}\text { Communicator and } \\
\text { Collaborator }\end{array}$ \\
\hline \multicolumn{3}{|l|}{ Nutrition and Health } \\
\hline \multicolumn{3}{|l|}{$\begin{array}{c}\text { Prevention and } \\
\text { Control of Infectious } \\
\text { diseases }\end{array}$} \\
\hline \multicolumn{3}{|l|}{$\begin{array}{c}\text { Prevention and } \\
\text { Control of non- } \\
\text { infectious diseases }\end{array}$} \\
\hline Mental Health & & \\
\hline
\end{tabular}

\section{Attributes}

Review revealed that attributes essential in medical professional for serving the communities are standardized universally and legalized nationally [21-23]. Refer Table 2 for list of attributes essential for medical professional. For imparting these attributes, however, the healthcare has to be equity-based and community centred for which hospitals have to extend services to communities' [7].

\section{Pedagogy}

Literature suggests that the pedagogy has to be a combination of objective-based and experiential [24,25]. Students therefore "learn through experiencing and the dynamics of a group process" [26].

\section{Assessment of The Relevance and Appropriateness of AKUMC's Undergraduate Public Health Curriculum to Community's Health Needs}

Using the developed framework, the AKUMC's undergraduate public health curriculum was reviewed to assess the relevance of the conceptual basis, content and skills and the appropriateness of the pedagogy to community's health needs.Analysis revealed that conceptually, the AKUMC's undergraduate public curriculum is based on rights approach, contemplates social factors as crucial determinants for health and uses Primary Health Care strategy to improve the health of the population. The curriculum aims to prepare health leadership in Pakistan; competent physician having sound foundation of basic biological and biomedical concepts and equipped with clinical and social sciences skills.Health leaders with these attributes are capable to serve both individuals and populations of rural and urban areas within limited financial and human resources. The curricular objectives are to help students: understand core Public Health concepts and issues; relate health to social, cultural, political, economic and environmental determinants; recognise public health strategies and technologies required to improve health of the population; interact with communities to get familiar with social norms and values; think critically to identify community's health problems; and use evidence-based strategies to solve health problem.

The AKUMC's undergraduate public health curriculum: teaches significant public health issues, priority health problems and research methods; imparts skills to review literature, think critically, solve problems, make evidence-based decisions and conduct research; and inculcates attributes so that they can be good team members as well as leaders, effective communicator and provide compassionate, ethical and culturally appropriate care with honesty and empathy. The themes covered are; health and disease, determinants of health, epidemiology, biostatistics, health systems, Primary Health Care and reproductive health.In addition students are also provided opportunity to conduct a small public health research project.The AKUMC's undergraduate public curriculum has a class room: field-based teaching/training ratio of 60:40. The concept are taught in classroom through interactive lectures while critical thinking and problem solving skills are imparted 
through small group tutorials using literature, documents, data, case-studies and case scenarios. Experiential learning pedagogy is used for behaviour modification and development of positive attitudes. In this pedagogy students are taken to community setting to learn through observation, interaction, enquiry, assessment and interpretation.

\section{Process-Success Stories, Challenges and Lessons Learnt}

\section{Success Stories}

The AKUMC's undergraduate public curriculum from inception till date has had piloted several innovations. Many of these innovations had resulted into successful outcome and therefore have been scaled-up at institutional and or country level.

Community-Oriented and Community-Based Curriculum and Pedagogy: The AKUMC's undergraduate public curriculum is a pioneer in the conceptualization and implementation of COCB curriculum and pedagogy. This pedagogy has been institutionalized at other departments/schools of the Aga Khan Medical College Hospital (AKMCH) including Family Medicine, Paediatric and Ob/ Gyn and School of Nursing. Moreover, both the curriculum and pedagogy has also been replicated at almost all private and several government medical colleges of the country.

Human Resource: Though all cadres of healthcare providers were trained on public health concepts, skills and attributes of working in-and-with communities, in particular however, a new cadre of healthcare providers namely 'Community Health Workers (CHWs)' was introduced. These CHWs were community women who were given basic training on health and social determinants. Community Health Sciences faculty developed so far has been providing technical support at national, regional and international levels. Moreover, the CHW model was adopted at national level by developing Lady Health Workers (LHWs).

Primary Health Care (PHC) Prototypes:PHC prototypes were established in selected communities with specified catchment population to; teach and train students on Primary Care using community-oriented community-based pedagogy and bring them close to the communities. The community-based primary healthcare prototypes provided opportunities for connecting students to communities for understanding their needs and social determinants, and primary level preventive and clinical teaching.

Health Management Information Systems (HMIS): A comprehensive HMIS was established to improve quality of PHC services and track health indicators of the catchment population. This HMIS was adapted by Pakistan's government while developing District Health Management Information System (DHMIS).

\section{Challenges}

CHS, during the last three decades, encountered several challenges including:

Saturation of Communities: Change in the focus of donor community from long-term development programs to short-term target oriented projects resulted in the reduction of the number of community health programmes which were used for training of students. This caused saturation of communities that affected community-based training activities.

Human Resource Drain-out: Introduction of COCB education in other private and public medical colleges and better economic opportunities in new bilateral and multilateral donor projects resulted in draining out of trained faculty. The biggest challenge was hiring and training of faculty to meet the human resource requirement for maintaining the quantity as well as the quality of teaching.

Insecurity due to Terrorism: Security threats because of terrorism intensely affected planned community-based teaching activities and hence reduced students' learning opportunities.

Lessons Learnt: Several important lessons have been learnt from this extremely rich experience of three decades; communitycentred development projects are crucial for COCB teaching; retention of mature, knowledgeable, motivated and experienced faculty is vital for maintaining the quality of teaching/training; and secure external environment is the prerequisite for experiential learning.

\section{Discussion and Conclusion}

Our analysis revealed that AKUMC's undergraduate communitybased and oriented public health curricular model is relevant to community's health needs.Realizing that good health is partly knowledge-based and partly socially driven $[27,28]$, the curriculum duly considers social and environmental factors as significant determinants for health.In contrast to many medical schools which even to date emphasize curative care; AKUMC's model is endeavouring to improve health through disease prevention and health promotion [29,31]. The curricular design is neither traditional [32-34] nor purely competency-based [35] as primary objectives are to equip medical students with: knowledge of public health concepts, issues and strategies; skills to critically analyse, synthesize and use information for problem solving; and attributes of working with and for communities.It is likely, though, that only few health professionals will become public health managers and leaders, while rest may opt for clinical tracks.

Yet however evidence indicates that clinicians better educated in public health issues and trained in community settings: have better understanding and awareness of the wider public health context in which they are practicing; are more compassionate and empathetic; effectively promote community health perspective; are a productive member of the interdisciplinary health team [36]; and are effective role-models, supervisors and teachers for the health teams $[37,38]$. Evidence shows that fragmented, out-dated and static curricula produce ill-equipped graduates with mismatch of professional competencies to patient and population priorities [39]. Literature identifies that a more coherent community-based public health mind-set is required for attainment of the wellbeing of the population [40]. For this, incorporation of population-based health principles and methods in the undergraduate medical education is needed $[41,42]$. This therefore suggests that undergraduate 
medical schools should review and update their curricula to; match competencies to population needs, develop leadership and team work to improve health system's performance, and inculcate critical reasoning, empathy and ethics.

Assessment further shows that the use of community-based experiential learning pedagogy, a teaching methodology primarily used in sociology [43], was an innovation in medical education in Pakistan. This was operationalized through establishment of community-based primary healthcare prototypes in selected communities with specified catchment population. Conceptually, these prototypes are the connection between medical education and health systems and in fact were new methods and means for medical education [44]. Such an approach is based on primary health care ideology that recognizes that community centeredness in healthcare delivery model is vital to improve health of the population $[45,46]$. There is ample evidence that such formative learning transforms experts to professionals who are competent caregivers, communicators, educators, team members, managers, leaders and policy makers [47-50]. This highlights the need to; expand the focus from only technical content to broader contextual understanding and move beyond predominant hospital orientation to primary care.

Community-based experiential learning approach in medical education, however, is difficult to design and slow to implement even in developed countries and extremely challenging in resource scares countries [51-53]. The challenge is even more daunting in countries where national health systems are functionally curative focused with very few community-based services [54]. The nongovernmental organizations are though providing some communitybased healthcare services, however sustaining these programmes at times becomes difficult because of donor's preference for short-term target oriented projects (Recommendations for the international system to support country-level processes, 2006). In order to transform community-oriented content to communitybased curriculum, government has to take the stewardship role in making the network of the Primary Level Healthcare Facilities (PLHF) functional.This will; link academia to health systems, contextualize medical education, sensitize students to community's needs, prepare them to work in community setting and help them understand the significance of interdisciplinary team [29].

We found that, AKUMC's model specifically hired and trained faculty for community-based teaching since health professionals trained in traditional medical schools are reluctant to work in communities $[27,55]$. However due to market demand, retention of experienced, skilled and motivated faculty became challenging. This suggests that strategies for the retention of trained workforce have to be given due consideration while planning human resource for health professional education [56]. The core content of public health oriented medical curriculum has though been recommended in literature extensively, educational reforms launched by many institutions in the region highlight the need to tailor medical education to recent community's needs [57-61]. So far however no uniform format exists to identify community's health needs [62].
Therefore, the biggest strength of this paper is the framework proposed to determine community's health needs that can update and reform medical curriculum.

It should however be remembered that this descriptive framework is an instrument to reach plausible conclusions about community's health needs. The analytical approach used is a technique used for the assessment of health needs and priorities [63] and is not a methodology of "hard" science to establish causality as in case of experiments conducted in laboratories under controlled environment. This analytical approach is useful in linking means to end in case of interventions that are made in real life settings where process and outcomes vary with time and context. This framework is a step towards the prime goal of medical education endorsed by undergraduate medical bodies even today i.e. matching medical curriculum to population's health needs. The 21st century envisions for all health professional in all countries to be educated to mobilise knowledge, engage in critical reasoning and ethical conduct so that they are competent to participate in patient and population centred health systems as members of locally responsive and globally connected teams [9]. This argues for the imperative of community based medical education despite the economic, political and social challenges that hound the world today.

\section{References}

1. Flexner A, Pritchett HS (1910) education in the United States and Canada. A report to the Carnegie Foundation for the advancement of teaching. 1926 The Journal of the American College of Dentists. the Carnegie Foundation for the advancement of teaching, New York, USA 1901: 346.

2. Frank JR, Mungroo R, Ahmad Y, Wang M, De Rossi S, et al. (2010) Medical teacher 32(8): 631-637.

3. Fox E (1997) Predominance of the curative model of medical care: a residual problem. JAMA 278(9): 761-763.

4. Walton H (1993) The Edinburgh declaration. Journal of the Royal Society of Medicine 86(3): 184.

5. Bollag U, Schmidt H, Fryers T, Lawani J (1982) Medical education in action: community-based experience and service in Nigeria. Medical Education 16(5): 282-289.

6. Harden R, Sowden S, Dunn WR (1984) Educational strategies in curriculum development: the SPICES model. Medical Education 18(4): 284-297.

7. Blig J, Prideaux D, Parsell G (2001) PRISMS: new educational strategies for medical education. Medical Education 35(6): 520-521.

8. Walter Spitzer's Report (1983) McGill University, Aga Khan University and Aga Khan Foundation 1983.

9. Frenk J, Chen Li, Bhutta ZA, Cohen J, Crisp N et al. (2010) Health professionals for a new century: transforming education to strengthen health systems in an interdependent world. The lancet 376(9756): 1923-1958.

10. Colleges AOAM (1998) Learning Objectives for Medical Student Education-Guidelines for Medical Schools, Medical School Objectives Project. NW Washington, DC Association of American Medical Colleges Vol: 20037-1134.

11. McKimm J MB (2009) Curriculum design and development. Br J Hosp Med 70(12): 714-717. 
12. Assembly UG (2002) International convention on economic, social and cultural rights.

13. Marmot M, Friel S, Bell R, Houweling TA, Taylor S (2008) Health CoSDo Closing the gap in a generation: health equity through action on the social determinants of health. The lancet 372(9650): 1661-1669.

14. Organization, WH (2012) Social determinants of health Executive Board Meeting Vol. $132^{\text {nd }}$ Geneva, USA.

15. Lobst WF, Sherbino J, Cate OT, Richardson DL, Dath D, et al. (2010) Competency-based medical education in postgraduate medical education. Medical teacher 32(8): 651-656.

16. Women U (1979) Convention on the elimination of all forms of discrimination against women.

17. Program UND (2013) United Nations Development Program: Human Development Report 2013, UNDP.

18. Khan YP, Bhutta SZ, Munim S, Bhutta ZA (2009) Maternal health and survival in Pakistan: issues and options. J Obstet Gynaecol Can 31(10): 920-929.

19. Pappas G, Akhtar T, Gergen PJ, Hadden WC, Khan AQ (2001) Health status of the Pakistani population: a health profile and comparison with the United States. American journal of public health 91(1): 93.

20. Studies NIPS (2013) Pakistan Demographic and Health Survey 2012-13 Islamabad National Institute of Population Studies. Islamabad, Pakistan. MEASURE DHS. ICF International. Calverton, Maryland, USA.

21. Council HECPPMaD (2011) Curriculum of MBBS Curriculum Development Project. Islamabad: Ministry of Education.

22. Matthew O Donnell (2012) 8 Vital Traits Every Allied Health Professional Should Have Health eCarrers Network 2015

23. Medicine, C. o. O. F. o. (2003) Essential Skills and Abilities Required for the Study of Medicine.

24. Fry HKS, Marshall S (2003) Understanding student learning. A handbook for teaching and learning in higher education: Enhancing academic practice.

25. RW T (1959) Basic principles of curriculum and instruction: Syllabus for Education (pp. 305). Chicago University of Chicago Press, USA.

26. Fry HKS, Marshall S (2003) Understanding student learning. A handbook for teaching and learning in higher education: Enhancing academic practice.

27. CLC (2010) Striking the right balance: health workforce retention in remote and rural areas. Bulletin of the World Health Organization 88(5): 323-323.

28. Pablos-Mendez A, Chunharas S, Lansang MA, Shademani R, Tugwell $P$ (2005) Knowledge translation in global health. Bulletin of the World Health Organization 83(10): 723-723.

29. Walter Spitzer's Report (1983) McGill University, Aga Khan University and Aga Khan Foundation 1983 Pakistan.

30. Billings JA, Block S (1997) Palliative care in undergraduate medical education: status report and future directions. JAMA 278(9): 733-738.

31. Carlson CEl, Ansari W (2001) Improving health: postgraduate public health education-experience from the UK. Africa Journal of Nursing \& Midwifery 3(1): 25-29.

32. Frank JR, Mungroo R, Ahmad Y, Wang M, De Rossi S, et al. (2010). Medical teacher 32(8): 631-637.

33. Lobst WF, Sherbino J, Cate OT, Richardson DL, Dath D, et al. (2010) Competency-based medical education in postgraduate medical education. Medical teacher 32(8): 651-656.

34. Kreisle R (2010) Defining and implementing competency in basic science education.
35. Saucier DSE, Kerr J, Konkin J, Oandasan I, Organek AJ, et al. (2012) Competency-based curriculum for family medicine. Canadian Family Physician 58(6): 707-708.

36. Ladhani Z, Stevens FJ, Scherpbier AJ (2014) Does community health care require different competencies from physicians and nurses? BMC medical education 14(1): 1 .

37. Irby DM, Cooke M, O Brien BC (2010) Calls for reform of medical education by the Carnegie Foundation for the Advancement of Teaching: 1910 and 2010. Academic Medicine 85(2): 220-227.

38. Prideaux D, Alexander H, Bower A, Dacre J, Haist S, et al. (2000) Clinical teaching: maintaining an educational role for doctors in the new health care environment. Medical Education 34(10): 820-826.

39. (2004) Joint Learning Initiative Human Resources for Health: Overcoming the crisis.

40. El Ansari W, Phillips CJ (2001) Empowering healthcare workers in Africa: partnerships in health-beyond the rhetoric towards a model. Critical Public Health 11(3): 231-252.

41. Ewles L, Simnett I (2003) Promoting health: a practical guide: Bailliere Tindal London.

42. Ibrahim MA, SL Carey TS, Wagner EH (2001) Population-based health principles in medical and public health practice. Journal of Public Health Management and Practice 7(3): 75-81.

43. Mooney LA, Edwards B (2001) Experiential learning in sociology: Service learning and other community-based learning initiatives. Teaching Sociology: 181-194.

44. Organization, WH (2008) Scaling up, saving lives Global Health Workforce Alliance. Geneva, USA.

45. El Ansari W (1998) Partnerships and new ways of learning: a second opinion. NHS Magazine 15(winter) 21.

46. LE, Simnet (1999) Promoting Health: A Practical Guide. (Fourth Edition ed.). London, Scutari, USA.

47. Asad K (2009) Failure analysis of Primary health Care in Pakistan and recommendations for change. Health Commission report Insaf Research Wing.

48. Benner PSM, Leonard V, Day L (2010) Educating nurses: A call for radical transformation. John Wiley \& Sons 42(2): 141-143.

49. Busing N, Rosenfield J, Rourke J (2009) The future of medical education in Canada (FMEC): A collective vision for MD education. The Association of Faculties of Medicine of Canada (AFMC).

50. The Prime Ministers Commission on the Future of Nursing and Midwifery in England. (2010) Prime Minister's Commission. Front Line Care: The future of nursing and midwifery in England.

51. Naylor CD (2006) Leadership in academic medicine: reflections from administrative exile. Clinical medicine 6(5): 488-492.

52. Siantz M, Meleis AI (2007) Integrating cultural competence into nursing education and practice: 21st century action steps. J Transcult Nurs 18(Suppl 1): 86S-90S.

53. YK, BZ S (2010) Challenges in China's health professional education. Paper presented at the Presentation at the second meeting of the Commission on Education of Health Professionals for the $21^{\text {st }}$ Century. Peking University, Beijing, China.

54. Ahemd J, Shiakh B (2011) The state of affairs of Primary health care facilities' in Pakistan. Where is the state'stewardship? EMHJ 17(7): 619623.

55. Yach D, Leeder SR, Bell J, Kistnasamy B (2005) Global chronic diseases. Science 307(5708): 317-317.

56. Organization, WH (2012) Toolkit for Country Health Workforce Strengthening Geneva: WHO. 
57. Carlson CEl, Ansari W (2001) Improving health: postgraduate public health education-experience from the UK. Africa Journal of Nursing \& Midwifery 3(1): 25-29.

58. Cooke M, Irby DM, O Brien BC (2010) Educating physicians: a call for reform of medical school and residency John Wiley \& Sons p. 16.

59. Council HECPPMAD (2011) Curriculum of MBBS Curriculum Development Project. Islamabad: Ministry of Education, Pakistan.

60. Hernandez LM, Rosenstock L, Gebbie K (2003) Who will keep the public healthy?educating public health professionals for the $21^{\text {st }}$ century: National Academies Press, USA.

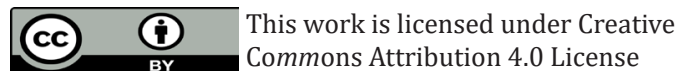

Submission Link: https://biomedres.us/submit-manuscript.php
61. Veenema TG (2001) An evidence-based curriculum to prepare students for global nursing practice. Nursing and Health Care Perspectives 22(6): 292-298.

62. Ladhani Z, Stevens FJ, Scherpbier AJ (2014) Does community health care require different competencies from physicians and nurses? BMC medical education 14(1): 1 .

63. KJ (1996) Health policy and systems development: an agenda for research.

\begin{tabular}{ll} 
BIOMEDICAL & Assets of Publishing with us \\
RESEARCHES & - Global archiving of articles \\
\hline & - Immediate, unrestricted online access \\
\end{tabular}

